DIMENSI, VOL. 8, NO. 1 : 116-126

MARET 2019

ISSN: 2085-9996

\title{
HUBUNGAN MOTIVASI BELAJAR DAN SOSIAL EKONOMI ORANG TUA TERHADAP HASIL BELAJAR MATEMATIKA SISWA KELAS XI SMA ANANDA BATAM
}

\section{THE RELATIONSHIP OF PARENTS 'LEARNING AND SOCIAL ECONOMIC MOTIVATION ON STUDENTS' LEARNING OUTCOMES IN MATHEMATICS CLASS XI ANANDA BATAM HIGH SCHOOL}

\author{
Eva Solina Sinaga ${ }^{1}$, Nailul Himmi Hasibuan ${ }^{2}$ \\ ${ }^{1,2}$ Prodi Pendidikan Matematika, FKIP, UNRIKA, Indonesia \\ ${ }^{1}$ Email: eva_solinasinaga@yahoo.com \\ ${ }^{2}$ Email: nailul.hsb@gmail.com
}

\begin{abstract}
Penelitian ini bertujuan untuk mengetahui: (1) Hubungan antara motivasi belajar dan hasil belajar matematika. (2) Hubungan antara sosial ekonomi dan hasil belajar matematika. (3) Hubungan motivasi belajar dan sosial ekonomi secara bersama-sama terhadap hasil belajar matematika. Jenis penelitian ini adalah penelitian korelasional. Populasi Penelitian ini adalah seluruh siswa kelas XI SMA Ananda Batam. Metode Pengamblian sampel dilakukan dengan sampel jenuh dengan total sampel sama dengan total populasi. Instumen penelitian ini menggunakan angket dan dokumentasi. Uji instrumen dilakukan menggunakan uji validitas yaitu validitas konstruk dengan rumus Product Moment dan uji reliabilitas dengan rumus Alpha Cronbach. Uji analisi data menggunakan uji korelasi sederhana dan korelasi ganda. Hasil penelitian menunjukkan: (1) Adanya hubungan yang positif dan signifikan antara motivasi belajar terhadap hasil belajar matematika. (2) Tidak adanya hubungan yang positif dan signifikan antara sosial ekonomi terhadap hasil belajar matematika. (3) Adanya hubungan antara motivasi belajar dan sosial ekonomi orang tua terhadap hasil belajar matematika.
\end{abstract}

Key words: Motivasi Belajar, Sosial Ekonomi Orangtua, Hasil Belajar Matematika

\begin{abstract}
Abstrak
This study aims to determine: (1) The correlation between motivation learning with outcomes of mathematics learning. (2) The correlation between social economics parents with the outcomes of mathematics learning. (3) The correlation of motivation learning and social economy parent together with the outcomes of mathematics learning. This type of research is correlational research. The population of this study were all students of class XI of Ananda Batam High School totaling 61 students. Sampling method is done with sensus samples with a total sample equal to the total population. This research instrument uses questionnaires and documentation. Instrument testing was carried out using validity test, namely construct validity with Product Moment formula and reliability test with Alpha Cronbach formula. Data analysis test using simple correlation test and multiple correlation. The outcomes of research indicate: (1) There is a positive and significant correlation between learning motivation with the outcomes of mathematics learning. (2) There is no positive and significant correlation between social economic with the outcomes of mathematics learning. (3) There is a correlation between learning motivation and social economic parents with the outcomes of mathematics learning.
\end{abstract}

Keywords: Motivation learning, Social economic of parents, Outcomes of mathematics learning 


\section{Pendahuluan}

Matematika sering dianggap sebagai ilmu yang hanya menekankan pada kemampuan berpikir logis dengan penyelesaian yang tunggal dan pasti. Oleh karena hal itulah matematika menjadi mata pelajaran yang ditakuti dan dijauhi siswa. Padahal, disetiap jenjang pendidikan matematika pasti dipelajari dan bahkan matematika adalah menjadi salah satu pengukur (indikator) keberhasilan siswa dalam menempuh suatu jenjang pendidikan, serta menjadi materi ujian untuk seleksi penerimaan menjadi tenaga kerja di bidang tertentu. Dengan merujuk akan kenyataan tersebut dapat ditarik kesimpulan bahwasanya matematika tidak hanya digunakan sebagi acuan untuk melanjutkan pendidikan yang lebih tinggi saja tetapi juga digunakan dalam mendukung karir seseorang. Sehingga besar harapan setiap guru, terlebih guru matematika yang ada agar siswa boleh mengerti, memahami materi pembelajaran matematika untuk mendapatkan hasil belajar minimal mencapai KKM.

Kenyataan yang terjadi pada saat proses pembelajaran masih banyak ditemukan kegagalan siswa untuk mengerti dan juga memahami materi sehingga hasil yang diharapkan mencapai KKM hanya tinggal harapan. Bahkan beberapa siswa menjadikan matematika sebagai mata pelajaran yang tidak disukai, sehingga mereka tidak menyukai atau meminati mata pelajaran tersebut. Hal ini yang memicu mengapa nilai hasil belajar pada mata pelajaran matematika sendiri banyak yang berada dibawah batas KKM. Untuk KKM mata pelajaran matematika di SMA Ananda Batam adalah 70.

Menurut Uno (2011) mengemukakan bahwa hasil belajar adalah semua efek yang dapat dijadikan indikator tentang nilai dari penggunaan suatu metode dibawah kondisi yang berbeda. Artinya hasil belajar biasanya mengikuti pelajaran tertentu yang harus dikaitkan dengan pencapaian tujuan yang telah ditetapkan. Tujuan instruksional pada hakikatnya adalah perubahan tingkah laku, yang diinginkan pada peserta didik, Sudjana (2009). Menurut Bloom dalam Chatarina (2007) menyebutkkan bahwasanya kemampuan manusia dikelompokkan ke dalam tiga ranah yaitu ranah kognitif, ranah afektif dan ranah psikomotorik. Untuk melihat tingkat hasil belajar siswa, berikut tabel hasil belajar yang diperoleh dari guru mata pelajaran matematika sesuai dengan hasil nilai ulangan harian semester II siswa kelas X SMA Ananda Batam Tahun Ajaran 2017/2018. 
DIMENSI, VOL. 8, NO. 1 : 116-126

MARET 2019

ISSN: 2085-9996

Tabel 1. Nilai Hasil Belajar Ulangan Harian Siswa

\begin{tabular}{cccc}
\hline Kelas & Jumlah Siswa & Rata-Rata Kelas & Persentase \% \\
\hline X1 & 23 & 74.78 & 65.22 \\
X2 & 20 & 70.00 & 60.00 \\
X3 & 20 & 67.00 & 50.00 \\
\hline
\end{tabular}

Sumber: Hasil Pengolahan Data, 2019

Berdasarkan data yang didapat terlihat bahwa hasil belajar siswa masih rendah karena dari persentase ketuntasannya berada dirata-rata $58.41 \%$. Jika dihitung dengan persentasi ketuntasan belajar klasikal jumlah siswa yang mendapat nilai $\geq 70$ adalah 37 siswa dibagi dengan total anak 63 siswa dan hasilnya dikalikan 100\% maka mempunyai nilai hasil persentase $58,73 \%$. Ketuntasan belajar klasikal dinyatakan berhasil jika persentase siswa yang tuntas belajar atau siswa yang mendapat nilai $\geq 70$ jumlahnya lebih besar atau sama dengan $85 \%$ dari jumlah siswa seluruhnya.

Ada beberapa faktor yang sangat mempengaruhi siswa sehingga tidak mampu memperoleh hasil belajar yang tidak mencapai KKM. Faktor tersebut berasal baik dari dalam diri siswa bahkan ada juga yang berasal dari luar diri siswa (dari orang lain ataupun dari lingkungan sekitar) yang sangat mempengaruhi siswa dalam meraih hasil belajar pada mata pelajaran matematika. Salah satu faktor yang mempengaruhi hasil belajar adalah motivasi. Menurut Mc. Donald (dalam Sardiman, 2012) motivasi adalah perubahan energi dalam diri seseorang yang ditandai dengan munculnya feeling dan didahului dengan tanggapan terhadap adanya tujuan. Sering terjadi siswa yang kurang berprestasi bukan disebabkan oleh kemampuannya yang kurang, akan tetapi dikarenakan tidak adanya motivasi untuk belajar sehingga ia tidak berusaha untuk mengerahkan segala kemampuannya.

Menurut Yudhawati \& Haryanto (2011) berpendapat bahwa motivasi dapat diartikan sebagai kekuatan (energi) seseorang yang dapat menimbulkan tingkat persistensi dan antuasiasisme dalam melaksanakan suatu kegiatan, baik yang bersumber dari dalam individu itu sendiri (motivasi intrinsik) maupun dari luar individu (motivasi ekstrinsik). Menurut Djaali (2012) mengatakan bahwa motivasi adalah kondisi fisiologis dan psikologis yang terdapat dalam diri seseorang yang mendorongnya untuk melakukan aktivitas tertentu guna mencapai 
suatu tujuan (kebutuhan). Dalam bahasa sederhana, motivasi adalah sesuatu yang menyebabkan anda berjalan, membuat anda tetap berjalan, dan menentukan ke mana anda berusaha berjalan (Slavin, 2009). Siswa yang memiliki motivasi yang kuat, akan mempunyai keinginan untuk melaksanakan kegiatan belajar mengajar, sehingga memungkinkan ia akan mendapatkan hasil belajar yang baik pula. Dengan kata lain motivasi, usaha, dan hasil belajar mempunyai hubungan searah. Motivasi berasal dari dalam dan luar diri seseorang. Namun pada saat penulis melakukan observasi dengan mewawancarai Bu Nelda selaku guru mata pelajaran matematika memberikan pendapat bahwasanya siswa mempunyai banyak karakter, sehingga ada beberapa siswa yang sudah mempunyai motivasi dari dalam dirinya dan ditambah motivasi dari guru serta orang dapat memiliki nilai yang tinggi, namun ada yang motivasi dalam dirinya sangat rendah dibantu pacu dengan motivasi dari guru serta orang tua tetapi hasil belajarnya juga masih kurang. Dapat disimpulkan motivasi instrinsik dan ekstrinsik sama-sama mempengaruhi hasil belajar siswa.

Dari observasi yang dilakukan didapati secara langsung bahwa motivasi belajar siswa rendah. Hal ini ditunjukkan pada saat proses belajar mengajar bahwasanya siswa tidak menunjukkan kesiapannya dalam belajar, contohnya saja buku pelajaran baik LKS, buku cetak, maupun buku tulis mereka ketinggalan dirumah karena tidak dipersiapkan sebelumnya. Selain itu, pada proses belajar tidak tampaknya semangat siswa dalam memperhatikan penjelasan materi oleh guru mata pelajaran.

Selain motivasi, pada saat penulis observasi di SMA Ananda Batam banyak hal yang terlihat menjadi penyebab mengapa hasil belajar tidak mencapai KKM. Salah satu penyebab permasalah ini terjadi bersumber dari lingkungan keluarga. Dimana kasus sosial ekonomi orang tua siswa merupakan salah satu faktor mempengaruhi hasil belajar siswa. Hal ini didukung oleh pernyataan oleh salah seorang guru matematika di SMA Ananda, Ibu Nelda Hutauruk yang mengatakan bahwasanya perilaku anak sangat dipengaruhi ruang lingkup keluarga yang berkaitan dengan sosial ekonomi orang tua.

Faktor sosial ekonomi orang tua diduga juga mendukung hasil belajar. Dalam struktur sosial banyak dijumpai berbagai aspek perilaku sosial dimasyarakat, Abdulsyani (2012) menerangkan bahwa: Perilaku sosial menunjukkan adanya suatu gejala yang tetap pada 
kehidupan masyarakat setelah melalui tahapan perubahan-perubahan tertentu. Dengan struktur sosial, maka secara psikologis anggota masyarakat merasa ada batas-batas tertentu dalam setiap aktivitasnya, individu senantiasa menyesuaikan diri dengan ketertiban dan keteraturan masyarakat yang ada.

Menurut Iskandarwassid \& Sunandar (2011) mengungkapkan bahwa keberhasilan belajar anak di sekolah dipengaruhi kemampuan sosial ekonomi orang tua yang merupakan latar belakang pencapaian posisi orang tua dalam masyarakat. Status sosial ekonomi seseorang berkaitan dengan partisipasi sesorang dalam kehidupan bersama sebagai kesatuan hidup bermasyarakat atau kelompok, yang menimbulkan dampak perkembangan dirinya sebagai individu.

Menurut William (2007) mengungkapkan bahwa kebahagian dan kemakmuran akan tetap ada dalam masyarakat jika saja semua orang bertindak 'benar' sebagai anggota keluarga dan menyadari bahwa orang harus mentaati kewajibannya sebagai anggota masyarakat. Karena untuk bisa memenuhi semua fasilitas belajar yang diperlukan anaknya setidaknya tingkat sosial ekonomi orang tua tinggi atau sedang. Dalam hal ini sosial ekonomi orang tua yang sangat dapat dilihat secara langsung dari segi tingkat pendidikan terakhir yang di tempuh dan juga besar pendapatan orang tua setiap bulannya.

\section{Metode Penelitian}

Jenis penelitian yang digunakan dalam penelitian ini adalah penelitian korelasional yaitu penelitian yang bertujuan untuk melihat hubungan antara dua variabel atau lebih (Siregar, 2013), desain penelitian ini adalah sebagai berikut:

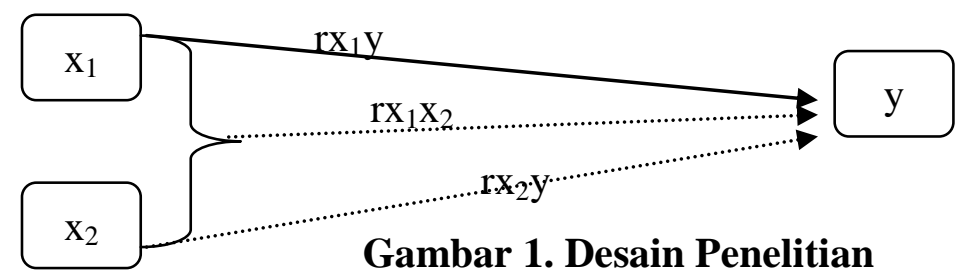

Populasi dalam penelitian ini adalah seluruh siswa kelas XI SMA Ananda Batam sebanyak 61 siswa. Pegambilan sampel pada penelitian ini adalah sampel jenuh. Sampel jenuh merupakan teknik penentuan sampel bila semua anggota populasi dijadikan sabagi sampel. 
Teknik ini dilakukan apabila populasi memiliki anggota yang relatif kecil (Sugiyono 2011). Jadi sampel dalam penelitian adalah seluruh siswa kelas XI SMA Ananda Batam.

Variabel bebas dalam penelitian ini adalah Motivasi Belajar $\left(\mathrm{X}_{1}\right)$, Sosial Ekonomi Orang Tua $\left(\mathrm{X}_{2}\right)$, sedangkan untuk variabel terikatnya adalah Hasil Belajar Matematika (Y).Teknik pengambilan data yang digunakan dalam penelitian ini menggunakan angket. Angket digunakan untuk mengukur Motivasi Belajar dan Sosial Ekonomi Orang Tua terhadap Hasil Belajar Matematika siswa.

Dari hasil uji validitas instrumen menggunakan validitas konstruk dengan rumus Pearson Product Moment (Sundayana, 2014) terdapat 32 soal yang valid untuk motivasi belajar dan 17 soal valid untuk sosial ekonomi orang tua. Sedangkan untuk menguji reliabilitas instrumen dalam penelitian ini menggunakan rumus Alpha Cronbach yang menurut Amirono dan Daryanto (2016) Alpha Cronbach yaitu teknik untuk menguji reliabilitas tes/alat pengukur yang butir soalnya menghendaki skor yang bertingkat (gradualisasi skor).

Hasil dari koefisien Alpha Cronbach untuk motivasi belajar menunjukkan angka 0,933 dan untuk sosial ekonomi orang tua menunjukkan angka 0,771 jadi karena angka yang didapat untuk uji reliabilitas kedua instrumen > 0,6, sehingga semua instrumen memiliki reabilitas. Untuk uji prasyarat analisis dalam penelitian ini adalah normalitas menggunakan Kolmogrov Smirnov sedangkan untuk uji hipotesis 1,2 dan 3 menggunakan analisis korelasi dengan rumus korelasi sederhana dan korelasi ganda. Untuk menentukan kekuatan hubungan, nilai koefisien korelasi berada diantara -1 sampai 1, sedangkan arah hubungan dinyatakan dalam bentuk positif (+) dan negatif (-). Apabila nilai $r=-1$ artinya korelasinya negatif sempurna, apabila nilai $r=0$ artinya tidak ada korelasi, sedangkan $r=1$ artinya korelasinya sangat kuat (Siregar 2015)

\section{Hasil Penelitian dan Pembahasan}

Setelah melakuka penelitian dengan menyebarkan angket kepada siswa kelas XI SMA Ananda Batam sejumlah 61 siswa sampel penelitin, maka diperoleh data hasil penelitian sebagai berikut: 
Tabel 2. Deskriptif Statistik Variabel Penelitian

\begin{tabular}{llllll}
\hline \multicolumn{1}{c}{ Variabel } & Min & Max & Sum & Mean & Std. Deviasi \\
\hline Motivasi Belajar & 47 & 94 & 4337 & 71,10 & 12,483 \\
Sosial Ekonomi Orang Tua & 32 & 60 & 2903 & 47,59 & 6,402 \\
Hasil Belajar Matematika & 50 & 90 & 4290 & 70,33 & 9,124 \\
\hline
\end{tabular}

Sumber: Hasil Penelitian Diolah, 2019

Sebelum data dianalisis untuk menguji hipotesis, terlebih dahulu data harus memenuhi syarat normal. Pada uji prasyarat ini uji normalitas menggunakan Kolmogrov Smirnov diperoleh nilai signifikan variabel Motivasi Belajar adalah 0,200; variabel Sosial Ekonomi Orang Tua adalah 0,200 dan variabel Hasil Belajar Matematika 0,055 maka dapat disimpulkan (Sig) > 0,05 jadi ketiga variabel tersebut dinyatakan berdistribusi normal. Untuk melihat histogram dari uji normalitas untuk setiap variabel dapat dilihat seperti berikut:
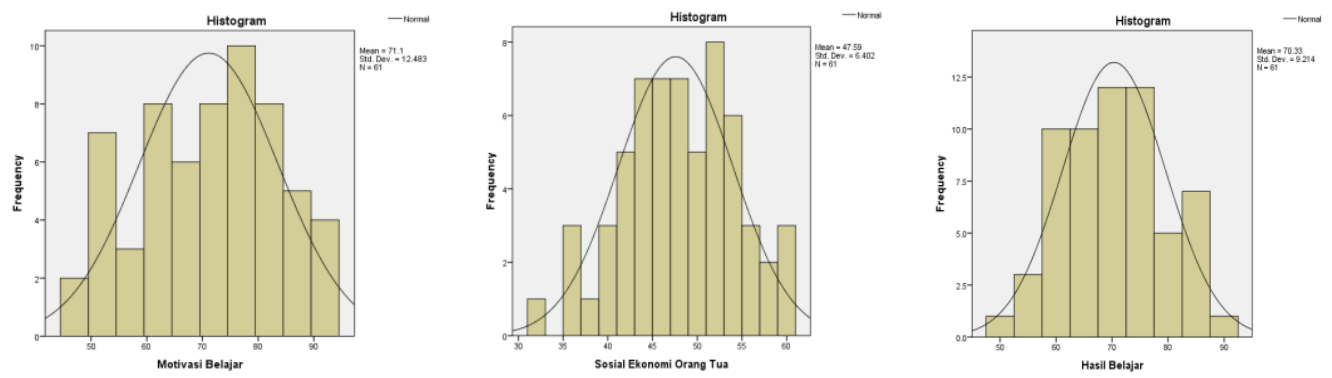

Gambar 2. Histogram Uji Normalitas Setiap Variabel

Adapun hasil pengujian hipotesis dalam penelitian ini dapat dilihat dengan tabel nilai korelasi dan signifikansi variabel bebas terhadap variabel terikat berikut:

\begin{tabular}{lll}
\multicolumn{2}{l}{ Tabel 3. Nilai Korelasi dan Signifikansi Variabel Bebas Terhadap Variabel } \\
Terikat
\end{tabular}

Sumber: Hasil Penelitian Diolah, 2019

Berdasarkan tabel di atas dapat dianalisis bahwa untuk nilai $r_{x_{1} y}=0,674$. Besar hubungan dalam kategori kuat, yaitu motivasi belajar memiliki hubungan yang kuat dengan hasil belajar matematika. Sedangkan arah hubungan adalah positif karena nilai r positif, yang 
artinya semakin tinggi motivasi belajar yang dimiliki oleh siswa maka semakin tinggi pula hasil belajarnya. Kemudian berdasarkan perhitungan di atas diperoleh uji signifikan sig = $0,000<\alpha=0,05$, sehingga keputusannya $\mathrm{H}_{0}$ ditolak. Artinya adanya hubungan yang positif dan signifikan antara motivasi belajar terhadap hasil belajar matematika siswa kelas X SMA Ananda Batam. Berdasarkan perhitungan koefisien determinasi diperoleh hasil 45,42\% dan sisanya 54,58\%. Artinya besar sumbangan motivasi belajar terhadap hasil belajar matematika siswa kelas X SMA Ananda batam sebesar 45,42 \%. Sisanya 54,58\% ditentukan oleh faktor lain yang tidak diteliti dalam penelitian ini.

Hubungan yang positif dan signifikan antara motivasi belajar dengan hasil belajar matematika dapat disebabkan oleh beberapa hal yang sesuai dengan indikator motivasi belajar. Semakin tinggi ketekunan dalam belajar dan keuletan dalam menghadapi kesulitan pada mata pelajaran matematika akan membuat siswa semakin memahami materi dan membuat hasil belajar matematika semakin tinggi. Minat dan ketajaman perhatian dalam belajar juga kesadaran akan prestasi dalam belajar akan membantu siswa mengerti bahwa tujuan dari pembelajaran tersebut. Menyontek akan membuat siswa akan semakin malas belajar sehingga kemandirian belajar siswa dibutuhkan dalam proses belajar. Ditambah lagi pengaruh dari luar diri siswa yaitu penghargaan atas prestasi belajar, hukuman atas kelalaian, perhatian orang tua dalam belajar, ketersediaan buku referensi menunjang pengetahuan dari beberapa sumber dan penggunaan internet dalam belajar mengikuti perkembangan jaman. Ketika setiap indikator dapat tercapai diharapkan hasil belajar mengalami peningkatan.

Berdasarkan hasil penelitian dapat dianalisis bahwa untuk nilai $r_{x_{2} y}=-0,044$. Besar hubungan dalam kategori sangat lemah, yaitu sosial ekonomi orang tua memiliki hubungan yang sangat lemah dengan hasil belajar matematika. Beberapa faktor yang mempengaruhi sangat lemahnya hubungan sosial ekonomi orang tua terhadap hasil belajar matematika siswa adalah tingkat pendidikan orang tua dan juga pekerjaan orang tua. Tingkat pendidikan orang tua mempengaruhi cara orang tua dalam mendidik anaknya, sedangkan ekerjaan orang tua mempengaruhi waktu kebersamaan orang tua dalam memperhatikan dan mengontrol anak. Untuk arah hubungan sosial ekonomi orang tua terhadap hasil belajar matematika siswa adalah 
negatif karena nilai $\mathrm{r}$ negatif, yang artinya semakin tinggi sosial ekonomi orang tua yang dimiliki maka semakin rendah hasil belajarnya. Kemudian berdasarkan perhitungan di atas diperoleh uji signifikan $\operatorname{sig}=0,735>\alpha=0,05$, sehingga keputusannya $\mathrm{H}_{0}$ diterima. Artinya tidak adanya hubungan yang positif dan signifikan antara sosial ekonomi orang tua terhadap hasil belajar matematika siswa kelas X SMA Ananda Batam. Berdasarkan perhitungan koefisien determinasi diperoleh hasil 19,36\% dan sisanya 80,64\%. Artinya besar sumbangan sosial ekonomi orang tua terhadap hasil belajar matematika siswa kelas X SMA Ananda batam sebesar $19,36 \%$. Sisanya $80,64 \%$ ditentukan oleh faktor lain yang tidak diteliti dalam penelitian ini.

Tidak adanya hubungan yang positif dan signifikan antara sosial ekonomi terhadap hasil belajar matematika dapat disebabkan beberapa hal dari indikator yang tidak tercapai. Seperti yang diketahui bahwasanya status sosial ekonomi dipengaruhi oleh pendidikan, pendapatan dan penghasilan. Jika diperhatikan dari data yang ada untuk tingkat pendidikan orang tua mayoritas menempuh jenjang SMA dengan persentase 53,28\%. Untuk pekerjaan mayoritas orang tua siswa bekerja sebagai wirausaha dan pegawai. Dengan merujuk pekerjaan, pendapatan orang tua para siswa pun dapat digolongkan pada tingkat tinggi. Sehingga untuk pemenuhan kebutuhan serta fasilitas pun terpenuhi. Berdasarkan pencapaian indikator tersebut mayoritas orang tua siswa kelas $\mathrm{X}$ dapat digolongkan pada keluarga kaya dan terpandang. Keluarga yang kaya dan terpandang mempunyai kecenderungan untuk memanjakan anaknya, akibatnya anak kurang dapat memusatkan perhatiannya dalam belajar. Hal tersebut juga akan mengganggu belajar anak. Keadaan ekonomi yang berlimpah ruah akan menjadi enggan belajar karena terlalu banyak bersenang-senang, sehingga dapat menghambat keberhasilan dalam belajar. Beberapa hal yang telah dijelaskan di atas yang menjadi salah satu penyebab bahwa tidak adanya hubungan antara sosial ekonomi terhadap hasil belajar matematika.

Berdasarkan hasil penelitian dapat dianalisis bahwa untuk ketiga variabel memperoleh nilai $R_{x_{1} x_{2} y}=0,686$ Menunjukkan bahwa hubungan antara motivasi belajar, sosial ekonomi orang tua dan hasil belajar matematika siswa berada pada tabel kriteria tingkat korelasi dan kekuatan yang kuat yaitu antara 0,60-0,799. Sedangkan arah hubungan adalah positif karena 
nilai r positif, yang artinya semakin tinggi motivasi belajar dan sosial ekonomi orang tua yang dimiliki oleh siswa maka semakin tinggi pula hasil belajarnya. Kemudian berdasarkan perhitungan di atas diperoleh uji signifikan sig $=0,000<\alpha=0,05$, sehingga keputusannya $\mathrm{H}_{0}$ ditolak. Artinya adanya hubungan yang positif dan signifikan antara motivasi belajar dan sosial ekonomi orang tua secara bersama-sama terhadap hasil belajar matematika siswa kelas X SMA Ananda Batam.

Berdasarkan perhitungan koefisien determinasi diperoleh hasil 47,05\% dan sisanya $52,95 \%$. Artinya besar sumbangan motivasi belajar dan sosial ekonomi orang tua secara bersama-sama terhadap hasil belajar matematika siswa kelas X SMA Ananda batam sebesar 47,05 \% dan sisanya 52,95\% ditentukan oleh faktor lain yang tidak diteliti dalam penelitian ini.

Fasilitas untuk menunjang proses belajar yang telah disediakan oleh orang tua dari hasil pendapatan yang diperoleh orang tua dari usaha kerjanya, harusnya diseimbangi dengan perhatian orang tua mengontrol anak-anak dalam menggunakan setiap fasilitas yang tersedia. Sehingga fasilitas yang ada dapat dipergunakan dengan baik, sehingga tujuan pemenuhan untuk harapan hasil belajar yang baik pun dapat tercapai.

Setelah diketahui hasil penelitian yang menyatakan terdapat hubungan yang positif dan signifikan antara motivasi belajar dan sosial ekonomi terhadap hasil belajar matematika, maka perlu bagi siswa untuk menyadari betapa pentingnya motivasi belajar dan didukung oleh sosial ekonomi orang tua yang membantu dalam mempersiapkan siswa sebelum belajar di sekolah seperti perlengkapan, peralatan sekolah serta hal-hal lainnya yang dibutuhkan siswa.

\section{Kesimpulan}

Berdasarkan penelitian dan pembahasan yang telah dilakukan diperoleh kesimpulan, yaitu:

1. Adanya hubungan yang positif dan signifikan antara motivasi belajar terhadap hasil belajar siswa kelas X SMA Ananda Batam diperoleh dari hasil korelasi Product Moment sebesar 0,674 yang tergolong dalam kategori kuat. 
2. Tidak adanya hubungan yang positif dan signifikan antara sosial ekonomi orangtua terhadap hasil belajar siswa kelas X SMA Ananda Batam diperoleh dari hasil korelasi Product Moment sebesar -0,044 yang tergolong dalam kategori sangat lemah.

3. Adanya hubungan yang positif dan signifikan antara motivasi belajar dan sosial ekonomi orang tua secara bersama-sama terhadap hasil belajar siswa kelas X SMA Ananda Batam diperoleh dari hasil korelasi Product Moment sebesar 0,686 yang tergolong dalam kategori kuat.

\section{Daftar Pustaka}

Amirono \& Daryanto. (2016). Evaluasi dan Penilaian Pembelajaran Kurikulum 2013. Yogyakarta: Penerbit Gava Media.

Anni, Chatarina Tri. (2007). Psikologi Belajar. Semarang: UPT UNNES Press.

Djaali. (2012). Psikologi Pendidikan. Jakarta: Bumi Aksara.

Sardiman, A.M. (2012). Interaksi dan Motivasi Belajar-Mengajar. Jakarta: Rajawali.

Siregar, Syofian. (2013). Metode Penelitian Kuantitatif dilengkapi dengan perbandingan perhitungan manual dan SPSS. Jakarta: Kencana.

Slavin, R.E. (2009). Psikologi pendidikan teori dan praktik. Jakarta: PT. Index.

Sugiyono. (2011). Metode Penelitian Kuantitatif Kualitatif dan R\&D. Bandung: Alfabeta.

Sudjana, Nana. (2009). Penilaian Hasil Proses Belajar Mengajar. Bandung: PT. Remaja Rosdakarya.

Uno, Hamsa B. (2011). Profesi Kependidikan, Problem, Solusi, dan Reformasi Pendidikan Indonesia. Jakarta: Bumi Aksara.

Iskandarwassid \& Sunandar, Dadang. (2011). Strategi Pembelajaran Bahasa. Bandung: PT. Remaja Rosdakarya.

William, G Goode. (2007). Sosiologi keluarga. Terjemahan Laila Hanoum Hasyim, Jakarta: Bumi Aksara.

Yudhawati, Ratna \& Haryanto, Dany. (2011). Teori-Teori Dasar Psikologi Pendidikan. Jakarta: Prestasi Pustaka Raya. 